\title{
Philosophy of Education
}

\section{K.N. Srivastava and Suresh Kumar Pandey}

Ram Yash P.G. College, Prayagraj, Uttar Pradesh, India

*Corresponding author: knsrivastava1951@gmail.com

Received: 23 Oct., 2020

Revised: 25 Nov., 2020

Accepted: 18 Dec., 2020

\begin{abstract}
This introductory article explains the coverage of this book, which is about the philosophical aspects of education. It explains that the philosophy of education is the branch of philosophy that addresses philosophical questions concerning the nature, aims, and problems of education. The book examines the problems concerning the aims and guiding ideals of education. It also explores the problems concerning students' and parents' rights, the best way to understand and conduct moral education, and the character of purported educational ideals
\end{abstract}

Keywords: education, philosophy, students' rights, parents' rights, moral education, educational ideals

\section{What Is Philosophy of Education?}

Philosophy of education is that branch of philosophy that addresses philosophical questions concerning the nature, aims, and problems of education. As a branch of practical philosophy, its practitioners look both inward to the parent discipline of philosophy and outward to educational practice, as well as to developmental psychology, cognitive science more generally, sociology, and other relevant disciplines.

The most basic problem of philosophy of education is that concerning aims: what are the proper aims and guiding ideals of education? A related question concerns evaluation: what are the appropriate criteria for evaluating educational efforts, institutions, practices, and

How to cite this article: Srivastava, K.N. and Pandey, S.K. (2020). Philosophy of Education. TechnoLearn: An International Journal of Educational Technology, 10(1\&2): 71-74. 
products? Other important problems involve the authority of the state and of teachers, and the rights of students and parents; the character of purported educational ideals such as critical thinking, and of purportedly undesirable phenomena such as indoctrination; the best way to understand and conduct moral education; a range of questions concerning teaching, learning, and curriculum; and many others.

\section{The Relation of Philosophy of Education to Philosophy}

For much of the history of Western philosophy, philosophical questions concerning education were high on the philosophical agenda. From Socrates, Plato, and Aristotle to twentiethcentury figures such as Bertrand Russell, John Dewey, R. S. Peters, and Israel Scheffler, general philosophers (i.e., contemporary philosophers working in departments of philosophy and publishing in mainstream philosophy journals, and their historical predecessors) addressed questions in philosophy of education along with their treatments of issues in epistemology, metaphysics, philosophy of mind and language, and moral and social/political philosophy. The same is true of most of the major figures of the Western philosophical tradition, including Augustine, Aquinas, Descartes, Locke, Hume, Rousseau, Kant, Hegel, Mill, and many others.

On the face of it, this should not be surprising. For one thing, the pursuit of philosophical questions concerning education is partly dependent upon investigations of the more familiar core areas of philosophy. For example, questions concerning the curriculum routinely depend on epistemology and the philosophies of the various curriculum subjects. Questions concerning learning, thinking, reasoning, belief, and belief change typically depend on epistemology, ethics, and/or philosophy of mind. Questions concerning the nature of and constraints governing teaching often depend on ethics, epistemology, and/or the philosophies of mind and language. Similarly, questions concerning schooling frequently depend on ethics, social/ political philosophy, and social epistemology. This sort of dependence on the parent discipline is typical of philosophical questions concerning education.

Another, related reason that the philosophical tradition has taken educational matters as a locus of inquiry is that many fundamental questions concerning education-for example, those concerning the aims of education, the character and desirability of liberal education, indoctrination, moral and intellectual virtues, the imagination, authenticity, and other educational matters - are of independent philosophical interest but are intertwined with more standard core areas and issues. In addition, the pursuit of fundamental questions in more or less all the core areas of philosophy often leads naturally to and is sometimes enhanced by sustained attention to questions about education. For these reasons, and perhaps others, it is not surprising that the philosophical tradition has generally regarded education as a worthy and important target of philosophical reflection. 
The next concerns a variety of issues involving thinking, reasoning, teaching, and learning. Richard Feldman discusses epistemological aspects of thinking and reasoning as they are manifested in the educational context. Jonathan Adler offers an account, informed by recent work in cognitive science as well as epistemology, of the nature of fallibility and its educational significance. Eamonn Callan and Dylan Arena offer an account of indoctrination, while Stefaan Cuypers does the same for authenticity. David Moshman provides a psychological account of the development of rationality, while Gareth Matthews raises doubts concerning the contributions developmental psychology might make to the philosophical understanding of the various cognitive dimensions of education. Thomas Brickhouse and Nicholas Smith offer a nuanced account of Socratic teaching and Socratic method, while Amélie Rorty argues for the educational importance of imagination and sketches strategies for developing it in the classroom.

The intersection of knowledge, curriculum, and educational research. David Carr addresses general questions concerning the extent to which, and the ways in which, the curriculum is and ought to be driven by our views of knowledge. Philip Kitcher focuses on the work of Dewey, Mill, and Adam Smith, arguing that Dewey's philosophy of education has the resources to answer a challenge posed by Smith's economic analyses, and that philosophers ought to embrace Dewey's reconceptualization of philosophy as the "general theory of education." Catherine Elgin discusses the character of art and the centrality of art education to the curriculum. Robert Audi and Richard Grandy both address questions concerning science education - the first focusing on the ways in which religious toleration and liberal neutrality might constrain science education, and the second on contemporary cognitive scientific investigations of teaching and learning in the science classroom. Denis Phillips assesses extant philosophical critiques of educational research and discusses the scientific status, current state, and future promise of such research.

Social and political issues concerning education. Amy Gutmann and Meira Levinson both address contentious questions concerning education in the contemporary circumstances of multiculturalism, while Lawrence Blum treats the problematic character and effects of prejudice and the prospects for overcoming them. Rob Reich investigates the moral and legal legitimacy of some varieties of educational authority, emphasizing the important but often overlooked interests of children.

\section{Bringing Philosophy of Education Back to Philosophy}

The time is right for philosophy of education to regain its rightful place in the world of general philosophy. Happily, there have been some positive developments on this score in recent years, as well as some honorable exceptions to the general neglect of philosophy of education in recent decades by the community of general philosophers. We must further 
C) Srivastava and Pandey

contribute to the restoration of philosophy of education to its rightful place in the world of general philosophy, by playing some role in furthering the recent rekindling of interest among general philosophers in philosophy of education: in their taking seriously philosophical problems concerning education, and in putting the latter on their philosophical agendas.

\section{REFERENCES}

Craig (pp. 231-40). London: Routledge.

Doyle, James F., ed. 1973. Educational Judgments: Papers in the Philosophy of Education. London: Routledge \& Kegan Paul.

Dewey. Glenview, IL: Scott, Foresman and Company.

Langford, Glenn, and D. J. O'Connor, eds. 1973. New Essays in the Philosophy of Education. London: Routledge \& Kegan Paul.

The Monist. 1968. General Topic: Philosophy of Education. Monist, 52: 1.

Siegel, Harvey. 2005. "Truth, Thinking, Testimony and Trust: Alvin Goldman on Epistemology and Education." Philosophy and Phenomenological Research, 71(2): 345-66.

- - (2007). “The Philosophy of Education." Encyclopaedia Britannica Online, September 2007, http://search. eb.com/eb/article-9108550. Forthcoming in Encyclopaedia Britannica, print version, pp. 9. 